\title{
Laparoscopic evaluation of tubal factor in cases of infertility
}

\author{
Shraddha K. Shetty ${ }^{1 *}$, Harish Shetty ${ }^{2}$, Supriya Rai ${ }^{2}$
}

\author{
${ }^{1}$ Department of Obstetrics and Gynaecology, Kasturba Medical College, Mangalore, Karnataka, India \\ ${ }^{2}$ Department of Obstetrics and Gynaecology, K.S. Hegde Medical Academy, Mangalore, Karnataka, India
}

Received: 5 August 2013

Accepted: 17 August 2013

\author{
*Correspondence: \\ Dr. Shraddha K. Shetty, \\ E-mail: shraddha_k1@rediffmail.com
}

(C) 2013 Shetty SK et al. This is an open-access article distributed under the terms of the Creative Commons Attribution Non-Commercial License, which permits unrestricted non-commercial use, distribution, and reproduction in any medium, provided the original work is properly cited.

\begin{abstract}
Background: Tubal factor infertility accounts for approximately $25-35 \%$ of cases of female infertility. The evaluation of the fallopian tube is necessary to determine the management plan for infertility. Tubal patency can be diagnosed by hysterosalpingography (HSG) or laparoscopy with chromopertubation. The aim of this study was to determine the role of laparoscopy in the evaluation of tubal factor in infertile women.

Methods: Fifty women presenting with complaints of primary and secondary infertility were investigated for tubal disease by laparoscopy at K. S. Hegde Charitable Hospital, Mangalore, from January 2007 to July 2008. Tubal patency was tested by chromopertubation using Methylene blue dye.

Results: Thirty four (68\%) patients were in primary infertility group while $16(32 \%)$ patients were in secondary infertility group. $88 \%$ women were in the age group of 21 to 35 years. In $64 \%$ of women, the duration of infertility was between 1 to 5 years whereas $32 \%$ cases had been infertile for 6 to 10 years. Tubal pathology was detected in $64.7 \%$ cases of primary infertility and $68.7 \%$ cases of secondary infertility. Bilateral tubal occlusion was found in $8 \%$ and unilateral occlusion in $28 \%$ cases.

Conclusion: Laparoscopy is an effective diagnostic tool for evaluation of tubal pathology. Laparoscopy and chromopertubation test should be recommended as a first step in the investigation of infertile women with tubal factor.
\end{abstract}

Keywords: Chromopertubation, Infertility, Laparoscopy, Tubal factors

\section{INTRODUCTION}

Tubal factor infertility accounts for a large portion of female factor infertility. The most prevalent cause of tubal factor infertility is pelvic inflammatory disease and acute salpingitis. The incidence of tubal damage after one episode of pelvic infection is approximately $12 \%, 23 \%$ after two episodes and $54 \%$ after three episodes. ${ }^{1,2}$

Proximal, distal, and peritubal damage can be caused by a number of pathologic processes such as inflammation, endometriosis, and surgical trauma. ${ }^{3}$

Genital tuberculosis is an important cause of female infertility in developing countries like India, Nepal,
Bangladesh and Pakistan. It is one of the major causes for severe tubal disease leading to infertility. Unlike pulmonary tuberculosis, the clinical diagnosis of GTB is difficult because in majority of cases the disease is either asymptomatic or has varied clinical presentation. ${ }^{4} \mathrm{~A}$ combination of clinical and laparoscopic diagnoses, along with endometrial histopathology studies, acid-fast bacillus culture, and polymerase chain reaction assays provides the best available method for the diagnosis of genital tuberculosis in infertile women. ${ }^{5}$

Tubal pathology impairs functions of the fallopian tube and reduces fertility. The degree of tubal pathology determines the possibility for fertility. The evaluation of the fallopian tube is necessary to determine the 
management plan of infertility. Hysterosalpingography (HSG) is often performed as a first line approach to assess tubal patency and the presence of adhesions; however, HSG has limitations in detecting tubal pathology. ${ }^{6}$

Laparoscopy and chromopertubation is widely considered the gold standard test for investigating tubal patency. Additionally, it allows assessment for peritubal disease, adhesions and endometriosis. This has led to a recommendation by the NICE (UK) that women suspected of having comorbidities (such as endometriosis and pelvic inflammatory disease should undergo laparoscopy so that pelvic and tubal pathology can both be assessed. ${ }^{7}$

The aim of the study was to evaluate the role of laparoscopy in diagnosis of infertile women with tubal factors.

\section{METHODS}

Fifty women presenting with complaints of primary and secondary infertility were investigated for tubal disease by laparoscopy at K.S. Hegde Charitable Hospital, Mangalore, from January 2007 to July 2008. Inclusion criteria were no prior pelvic surgery, no history of pelvic infection, normal bimanual pelvic examination, and normal semen parameters of partner. Those patients who had medical disorders and contraindication for laparoscopy were excluded from study. Laparoscopy was scheduled in proliferative phase of menstrual cycle.

\section{Methodology}

Laparoscopy was performed under general anaesthesia. A one $\mathrm{cm}$ incision was made within or just below the lower edge of the umbilicus. Through this incision the abdominal cavity is inflated with carbon dioxide gas and pneumoperitoneum being obtained. A trocar was inserted in the same region. The cannula of the trocar was left, and the trocar was pulled out. Then a laparoscope was introduced through the cannula. During the procedure, the pelvis was inspected, including uterus, fallopian tubes, uterosacral ligaments, and Pouch of Douglas. The tubes were inspected for any abnormality in their length and shape. Both ovaries were examined regarding their size, shape, thickness of peripheral follicles. Peritubal, periovarian and omental adhesions, tubo-ovarian masses, endometriotic deposits, fibroid, presence of fluid in the Pouch of Douglas or any other pathology, if present was noted. The patency of fallopian tubes was ascertained by injecting methylene blue or Gentian violet into the uterine cavity and its spill through the fimbrial ends was checked. Variables were age, primary and secondary infertility, duration of infertility, tubal patency (yes or no), bilateral tubal block and unilateral tubal block. The study protocol was approved by the Institutional ethics committee. Patients were enrolled after having provided their informed written consent.

\section{RESULTS}

There were $34(68 \%)$ cases of primary infertility and 16 $(32 \%)$ cases of secondary infertility. $88 \%$ women were in the age group of 21 to 35 years (Table 1). In $64 \%$ of women, the duration of infertility was between 1 to 5 years whereas $32 \%$ cases had been infertile for 6 to 10 years (Table 2). $86 \%$ women had regular menstruation while $14 \%$ had irregular cycles.

Table 1: Age distribution in cases of primary and secondary infertility.

\begin{tabular}{|cllll|}
\hline $\begin{array}{l}\text { Age in } \\
\text { years }\end{array}$ & $\begin{array}{l}\text { Primary } \\
\text { infertility }\end{array}$ & $\begin{array}{l}\text { Secondary } \\
\text { infertility }\end{array}$ & No. & $\begin{array}{l}\text { Total } \\
\%\end{array}$ \\
\hline $21-25$ & 8 & 1 & 9 & 18 \\
\hline $26-30$ & 11 & 7 & 18 & 36 \\
\hline $31-35$ & 11 & 6 & 17 & 34 \\
\hline $36-40$ & 4 & 2 & 6 & 12 \\
\hline Total & 34 & 16 & 50 & 100 \\
\hline
\end{tabular}

Table 2: Duration of infertility.

\begin{tabular}{|llllll|}
\hline Duration & Primary & Secondary & \multicolumn{2}{|c|}{ Total } \\
\cline { 5 - 5 } infertility & $\begin{array}{c}\text { Infertility } \\
\text { in }\end{array}$ & $\mathbf{N}$ & $\%$ \\
\hline $6-10$ & 23 & 9 & 32 & 64 \\
\hline $11-15$ & 10 & 6 & 16 & 32 \\
\hline $16-20$ & 0 & 1 & 2 & 4 \\
\hline
\end{tabular}

Diagnostic laparoscopy revealed normal pelvic organs in $8(16 \%)$ cases, Chronic pelvic inflammatory disease in 3 $(6 \%)$, endometriosis in $12(24 \%)$ and congenital anomalies of uterus in $1(2 \%)$ cases (Table 3$)$.

Table 3: Findings of diagnostic laparoscopy.

\begin{tabular}{|lll|}
\hline Findings & No. & Percentage \\
\hline Normal pelvic organs & 8 & 16 \\
\hline Chronic inflammatory disease & 3 & 6 \\
\hline Endometriosis & 12 & 24 \\
\hline $\begin{array}{l}\text { Congenital anomalies of uterus } \\
\text { and tubes }\end{array}$ & 1 & 2 \\
\hline Fibroids & 18 & 36 \\
\hline Polycystic ovaries & 8 & 16 \\
\hline
\end{tabular}


Table 4: Findings of chromopertubation.

\begin{tabular}{|lll|}
\hline Findings & No. & Percentage \\
\hline Bilateral block & 4 & 8 \\
\hline Unilateral block & 14 & 28 \\
\hline Peritubal adhesions (spill seen) & 4 & 8 \\
\hline Healthy and patent tubes & 28 & 56 \\
\hline
\end{tabular}

Findings of chromopertubation are shown in (Table 4). $8 \%$ cases had bilateral tubal block, $28 \%$ had unilateral block and in $8 \%$ cases though the tubes were found patent significant peritubal adhesions were noted.

Details of tubal pathology detected in cases of primary and secondary infertility are shown in (Table 5). Tubal pathology was detected in $64.7 \%$ cases of primary infertility and $68.7 \%$ cases of secondary infertility. Among those who had tubal pathology, nonspecific pelvic inflammatory disease was noted in $44.1 \%$ and genital tuberculosis was diagnosed in $2.9 \%$ cases.

Table 5: Details of tubal pathology detected in cases of primary and secondary infertility.

\begin{tabular}{|lllllll|}
\hline $\begin{array}{l}\text { Tubal } \\
\text { pathology } \\
(\mathbf{n = 3 3})\end{array}$ & $\begin{array}{l}\text { Primary } \\
\text { Infertility } \\
(\mathbf{n}=\mathbf{3 4})\end{array}$ & $\mathbf{N}$ & $\begin{array}{l}\text { Secondary } \\
\text { infertility } \\
(\mathbf{n}=\mathbf{1 6})\end{array}$ & $\begin{array}{l}\text { Total } \\
(\mathbf{n}=50)\end{array}$ \\
\hline $\begin{array}{l}\text { Nonspecific } \\
\text { pelvic } \\
\text { inflammatory } \\
\text { disease }\end{array}$ & 15 & 44.1 & 8 & 50 & 23 & 46 \\
\hline $\begin{array}{l}\text { Tuberculous } \\
\text { Salpingitis }\end{array}$ & 1 & 2.9 & 0 & 0 & 1 & 2 \\
\hline $\begin{array}{l}\text { Endometriosis } \\
\text { Congenital }\end{array}$ & 6 & 17.6 & 3 & 18.7 & 9 & 18 \\
\hline $\begin{array}{l}\text { anomalies } \\
\text { Ectopic } \\
\text { Pregnancy }\end{array}$ & 0 & 0 & 0 & 0 & 0 & 0 \\
\hline Total & 22 & 64.7 & 11 & 68.7 & 33 & 66 \\
\hline
\end{tabular}

Table 6: Complications of laparoscopy.

\begin{tabular}{|lcccc|}
\hline $\begin{array}{l}\text { Complications } \\
\text { of laparoscopy } \\
(\mathbf{n = 5 0})\end{array}$ & $\begin{array}{l}\text { Primary } \\
\text { infertility } \\
(\mathbf{n = 3 4})\end{array}$ & \multicolumn{2}{l|}{$\begin{array}{l}\text { Secondary } \\
\text { infertility } \\
(\mathbf{n}=16)\end{array}$} \\
\hline Pyrexia & 4 & 11.7 & 2 & 12.5 \\
\hline Right shoulder tip pain & 4 & 11.7 & 2 & 12.5 \\
\hline Nausea and Vomiting & 8 & 23.5 & 4 & 25 \\
\hline No complications & 18 & 52 & 8 & 50 \\
\hline
\end{tabular}

There were no complications in 52\% of primary and $50 \%$ patients with secondary infertility groups. The most common complications were pyrexia, shoulder tip pain, nausea and vomiting (Table 6).

\section{DISCUSSION}

In the present study, tubal pathology was detected in $66 \%$ cases and bilateral tubal block in $8 \%$ cases and unilateral block in $28 \%$ cases. These observations illustrate that the prevalence of tubal pathology in women complaining of infertility is high in our community. In Ikechebelu JI and Mbamara SU study, 39.5\% women had normal patent tubes while $(60.4 \%)$ had tubal pathologies like bilateral tubal occlusion in $(38.3 \%)$ and unilateral tubal occlusion in $(22.1 \%)$ women. ${ }^{8}$

In the current study, tubal disease was observed in $64.7 \%$ cases while Kanal P and Sharma S in their study, reported tubal blockage in $42.5 \%$ of primary infertility. ${ }^{9}$

Nonspecific pelvic inflammatory disease was observed in $15(44 \%)$ cases in primary infertility and $8(50 \%)$ cases in secondary infertility whereas in $\mathrm{N}$ Aziz study, Pelvic inflammatory disease was reported in $1(3.1 \%)$ and 2 $(16.7 \%)$ cases of primary and secondary infertility respectively. The common finding was tubal blockage in $7(21.9 \%)$ and $6(33.3 \%)$ cases of primary and secondary infertility respectively. ${ }^{10}$ After one episode of PID, a woman has an estimated $15 \%$ chance of infertility. After two episodes, the risk rises to $35 \%$. After three episodes, the risk for infertility is nearly $75 \%$.

In the present study, the diagnosis of genital tuberculosis was made by laparoscopy in $1(2 \%)$ cases. Bilateral tubal block was seen in the case. Sharma JB et al studied laparoscopic findings in genital TB in $47.1 \%$ cases. The various findings on laparoscopy were tubercles on peritoneum $(12.9 \%)$ or ovary $(1.2 \%)$, tubovarian masses $(7.1 \%)$, caseous nodules $(5.8 \%)$, encysted ascitis in $7.1 \%$ women. Various grades of pelvic adhesions were seen in $(65.8 \%)$ women. The various findings on fallopian tubes were normal looking tubes in $(7.1 \%)$, inability to visualize in $12(14.1 \%)$, presence of tubercles on tubes in $3(3.52 \%)$, caseous granuloma in $3(3.52 \%)$, hydrosalpinx in $15(17.6 \%)$ (Right tube $11.7 \%$, left tube $5.9 \%$ ), pyosalphinx in $3(3.5 \%)$ on right tube and $2(2.35 \%)$ in left tube, beaded tube in $3(3.5 \%)$ on right tube, $4(4.7 \%)$ in left tube with tobacco pouch appearance in $2(2.35 \%)$ women. ${ }^{11}$ Genital tuberculosis is common in India and a combination of clinical and laparoscopic diagnoses, along with endometrial histopathologic studies, acid-fast bacillus culture, and polymerase chain reaction assays provides the best available method for the diagnosis of genital tuberculosis in infertile women. ${ }^{12}$

Endometriosis was observed in $12(24 \%)$ cases in the present study but significant peritubal adhesions were found in $4(8 \%)$ cases whereas $\mathrm{N}$ Aziz reported 
endometriosis in $6(12 \%)$ cases and peritubal and periovarian adhesions in $6(12 \%)$ cases. $^{10}$

Laparoscopy remains the gold standard for diagnosis and surgical removal at that time should be first line treatment. ${ }^{13}$ Despite the fact that a causal relationship between endometriosis and infertility has not been clearly established, the fecundity rate of untreated women with endometriosis is lower than normal couples. ${ }^{14}$ Robabeh $\mathrm{M}$ and Roozbeh $\mathrm{T}$ in their comparative study of hysterosalpingography and laparoscopy, concluded that although laparoscopy is considered as the reference standard in infertility workup, HSG can be performed first and the use of laparoscopy should be limited to cases suspected for etiologies other than intratubal, such as endometriosis and peritubal adhesions. ${ }^{15}$

Tubal occlusion and peritubal or periovarian adhesions are factors responsible for inhibition of ovum pickup and transport. Laparoscopy is thus a definitive way to diagnose them.

Additional pelvic pathology was found in 26 (51.2\%) cases. The commonest was fibroids in 18 (36\%) cases and polycystic ovaries in $8(16 \%)$ cases. Similar results were observed in various other studies. ${ }^{8}$ Other pathologies observed include uterine anomalies (unicornuate uterus with one fallopian tube).

\section{CONCLUSION}

Tubal pathology was detected in $66 \%$ cases of infertile women in our study. These observations suggest that the use of laparoscopy and chromopertubation test should be recommended as a first step in the investigation of infertile women with tubal factor.

Funding: No funding sources

Conflict of interest: There are no conflicts of interest to declare

Ethical approval: The study was approved by the Institutional Ethical Committee

\section{REFERENCES}

1. Dun EC, Nezhat CH. Tubal factor infertility: diagnosis and management in the era of assisted reproductive technology. Obstet Gynecol Clin North Am. 2012 Dec;39(4):551-66.

2. Muzii L, Sereni MI, Battista C, Zullo MA, Tambone V, Angioli R. Tubo-peritoneal factor of infertility: diagnosis and treatment. Clin Ter. 2010; 161(1):7785.
3. Confino E, Radwanska E. Tubal factors in infertility. Curr Opin Obstet Gynecol. 1992 Apr;4(2):197-202.

4. Mondal SK, Dutta TK. A ten year clinicopathological study of female genital tuberculosis and impact on fertility. JNMA J Nepal Med Assoc. 2009 Jan-Mar; 48(173):52-7.

5. Gupta N, Sharma JB, Mittal S, Singh N, Misra R, Kukreja M. Genital tuberculosis in Indian infertility patients. Int J Gynaecol Obstet. 2007 May; 97(2):135-8.

6. Tsuji I, Ami K, Fujinami N, Hoshiai H. The significance of laparoscopy in determining the optimal management plan for infertile patients with suspected tubal pathology revealed by hysterosalpingography. Tohoku J Exp Med. 2012; 227(2):105-8.

7. National Institute for Clinical Excellence, NHS. Fertility: Assessment and Treatment for People with Fertility Problems- Full Guideline. London: RCOG Press, 2004.

8. Ikechebelu JI, Mbamara SU. Should laparoscopy and dye test be a first line evaluation for infertile women in southeast Nigeria? Niger J Med. 2011 Oct-Dec; 20(4):462-5.

9. Kanal P, Sharma S. Study of Primary Infertility in females by Diagnostic Laparoscopy. Internet Journal of Medical Update 2006 Jul-Dec;1(2):7-9.

10. Aziz N. Laparoscopic evaluation of female factors in infertility. J Coll Physicians Surg Pak. 2010 Oct; 20(10):649-52.

11. Sharma JB, Roy KK, Pushparaj M, Kumar S, Malhotra N, Mittal S. Laparoscopic findings in female genital tuberculosis. Arch Gynecol Obstet. 2008 Oct; 278(4):359-64.

12. Gupta N, Sharma JB, Mittal S, Singh N, Misra R, Kukreja M. Genital tuberculosis in Indian infertility patients. Int J Gynaecol Obstet. 2007 May; 97(2):135-8

13. O'Callaghan D. Endometriosis--an update. Aust Fam Physician. 2006 Nov;35(11):864-7.

14. Bedoschi G, Turan V, Oktay K. Fertility preservation options in women with endometriosis. Minerva Ginecol. 2013 Apr;65(2):99-103.

15. Robabeh M, Roozbeh T. Comparison of hysterosalpingography and laparoscopy in infertile Iranian women with tubal factor. Ginekol Pol. 2012 Nov;83(11):841-3.

DOI: $10.5455 / 2320-1770 . i j r \operatorname{cog} 20130930$

Cite this article as: Shetty SK, Shetty H, Rai S. Laparoscopic evaluation of tubal factor in cases of infertility. Int J Reprod Contracept Obstet Gynecol 2013;2:410-3. 